\title{
An Assessment of the Performance of Public Enterprise Sector in Nigeria
}

\author{
Prof. Adam A. Anyebe* \\ Department of Public Administration, Faculty of Administration, Ahmadu Bello University, Zaria \\ *Corresponding Author: Prof. Adam A. Anyebe, Department of Public Administration, Faculty of \\ Administration, Ahmadu Bello University, Zaria
}

\begin{abstract}
Public enterprise has long been an important instrument of public intervention in the development process in Nigeria. So, from within the public sector, there has been in the country emergence and development of public enterprises that combine the characteristics of public administration with some key attributes of a private enterprise. These entities are usually created because of the desire to infuse more flexibility and more efficiency in the organisation of some government activities. This sector, however, has been facing serious challenges from privatisation movement since the mid-1970 as its theories and assumptions came under severe attack. The size and importance of the sector has since been declining. This paper, therefore, attempted to assess the performance of public enterprises in the country on two issues autonomy issues and return on investment. The study used mainly secondary data for its analysis. It was revealed that the quantifiable return on the large volume of investment in the public enterprise sector in Nigeria, for example, was not seen as satisfactory in the light of the realities of the country's economy in the 1980s. Almost all the enterprises operated at sub-optimal levels. There were huge losses in many cases, and these losses were charged against public treasury.It was, therefore, recommended that achieving improved performance in public enterprise sector in Nigeria requires more far-reaching reforms and greater commitment on the part of government.
\end{abstract}

Keywords: Public enterprise, Performance, Autonomy, Return on investment, Development

\section{INTRODUCTION}

One reason for establishing public enterprises, especially in developing countries, was to stimulate and accelerate national development under conditions of chronic shortage of capital and structural defects in capital markets. Also, in an attempt to preserve their independence, national pride and sovereignty, these countries foreclosed market liberalisation option for economic development. It was then felt that government was the only organised agent capable of employing its machinery to induce, promote, and manage socio-economic development. Thus, in the post-independence era, government became the prime agent of economic development, providing infrastructure, and producing goods and services, often provided through the mechanism of public enterprise. Developing countries including Nigeria, therefore, used public enterprises to a greater extent than most western countries.

In Nigeria, if economic success had followed, the public enterprise sector would have been lauded. In 1987, the Nigerian economy declined when the country was in no less than 1,500 enterprises spanning transport, aviation, shipping, oil, vehicle assembly, and manufacturing (Anyebe, 2012). Instead of serving as an agent of national development, many of these enterprises served only the interests of their managers and employees. This paper, therefore, attempted to assess the performance of public enterprises in Nigeria on two issues - autonomy issues and return on investment.

\section{Method of Data Collection}

The data for this study were collected from secondary sources. The secondary data employed in the study were thus obtained mainly from the following sources:

- Privatisation Hand Book, 2004 Edition, a Publication of Bureau of public Enterprise

- The Nigerian 1975-80 National Development Planning Document, Vol 1

- Newswatch Magazine, May 30, 1989 
- The 1983 Report of the Administrative Staff College of Nigeria (ASCON)

- Relevant textbooks

\section{RESULTS AND DiSCUSSION}

The performance of public enterprises in Nigeria was assessed on two issues (autonomy issues and return on investment).

\subsection{Autonomy Issues}

In Nigeria, the phenomenon of external control or interference rarely ever escapes mention in studies and writings on public enterprises. This is because hardly any senior official in a public enterprise fails to point at it, openly or anonymously, whenever an opportunity avails itself. The way it is expressed depicts it as contrary to the principle of autonomy granted to a public enterprise at birth. For example, Fabura (1984) states that, in most government-owned public companies:

Government determines the financial pricing and distribution policies. And various competing extraneous authorities like the head of government, the chairman of ruling party, the ministry of finance and the controlling ministry, all influence decisions of the boards, and therefore, keep the chief executive on his toes trying to manipulate their influences for his convenience. In effect because the chief executive has too many bosses whom he must please, he has little time to plan for the success of his company. He resorts to power games. Here lies the problem of government companies and their inability to perform efficiently.

In a study of 'Power Behind the Veil' of Policy Processes in Nigerian Public enterprises, Fabura (1984) explains how informal mechanisms are used by the board to coerce executive actions towards their favoured positions. Employees of these organisations often resent the action-stiffing interference of government agencies to which parastatals are responsible.

The Federal Government of Nigeria sought a consultancy study of management problems of public enterprises and parastatals from the Administrative Staff College of Nigeria (ASCON) in 1983. The Report indicates that:

One such impediment is the administrative structure which government itself has foisted upon them. On one side, there is a governing council or board of directors, mostly without professional knowledge relevant to the activity. This board has wide-range powers over policy matters and over matters of staff recruitment, promotion and discipline. On the other side, the management largely composed of professionals, whose role is to run the organisation and execute the policies laid out by the board of directors. Somewhere in the middle comes the supervising ministry, with a confusing role in its relationship to the board and management. It is possible, presumably, for this arrangement to work where each group of functionaries is prepared to keep within the strict limits of its powers and responsibilities. But in the fractions of social and political climate of our country, aggravated as it is by ethnic, political, egoistic, and other ambitions, these limits are continuously breached. The consequences have been that hostile relationship always exists between board and management, leading to frequent disruptions in the runnings of these establishments (The 1983 ASCON Report).

Tokunboh, a one-time chief executive of aparastatal, complained that it became impossible to manage with firmness capital development projects approved by the board. After unnecessary haggling, it would take months to gain ministerial approval. Appointments were controlled by politically appointed board members while the controlling ministries interfered practically in everything. She further stated that the situation led to public enquiries into almost all the country's major corporations. A study of NEPA drew attention to how long-range plans submitted to its controlling ministry were subjected to so much delay that plans were overtaken by environmental events and changes (Ojobo, 2010).

\subsection{Return on Investment}

Questions are naturally asked about the return on the investment in various public enterprises, the opportunity costs and priorities in view of new economic realities. From the stand-point of return on investment, there is sufficient evidence that in the main, public enterprises have proved a massive 
failure compared with results from similar investment in the private sector. In terms of their social objectives, including the provision of employment opportunities and the modernisation factor, their general inefficiency has made it almost impossible to achieve any meaningful result. One thus finds scattered across the country the skeletons of general government companies whose birth-days were marked with fun-fare several years earlier.

The performance of public enterprises in Nigeria at both the sectoral and sub-sectoral institutional levels has therefore, been a subject of considerable discussion by scholars. For example, Ayodele (1996), and Iwayemi (1990) provide comprehensive analysis of the dismal performance of public enterprises especially before the introduction of Structural Adjustment Programme (SAP) in Nigeria in 1987. This dismal performance reflects public enterprises failure to meet public aspirations in terms of the quantum of output as well as the quality of services, generation of any reasonable rates of return to investment capital expenditure and the provision of adequate and reliable services.

Some scholars such as Iwayemi (1990) and Ayodele et al (1995) observe the voltage peculiarities of electricity utility to explain inadequacies in the production systems of utilities in Nigeria in the 1960s through the first half of the 1980s. The situation in the 1989/90 fiscal year was nowhere different from the past trends shown in these previous studies. For example, total installed capacity in 1989/90 as shown in NEPA Plc's records was about 5,702 mw. The composition of this capacity is as follows: total hydro-power capacities in Kainji $(760 \mathrm{mw})$, Jebba $(540 \mathrm{mw})$, and Shiroro (60 mw); thermal capacity at Egbin (1320 mw), Sapele, (120 mw), Afam I III (580 mw) and Delta I III (840 mw).

Available capacity from this installation was roughly 3,000 $\mathrm{mw}(53 \%)$. However, the effective capacity was about $40 \%$ of installed capacity. That is, of an installed capacity of about 5,702 mw in 1989/90, only 2,280 mw was effective for electricity generation (News Watch Magazine, May 30, 1989: 14-19). In other words, there is capacity under-utilisation. In fact, the situation was the same in the NRC, WCN, NAL, etc., due to reasons connected with unavailability of spare parts, frequent breakdown of machines because of irregular servicing and inadequacy of maintenance and hydraulic problems in the cases of hydro projects.

The overall effects of these inadequacies result in serious supply-demand imbalances reflecting supply shortages. These shortages are usually met with load shedding, rationing and demand suppression devices. This situation remained the same for the transport and telecommunications services where demands overrode supplies. In other words, the provision of infrastructures in Nigeria remains weak (Iwayemi, 1990).

The World Bank Development Report (1990) reveals that the costs of this weak infrastructure, particularly for manufacturing enterprises, are very high. The Report stated that for every firm of more than 50 employees under surveillance, there was a privately owned stand-by generator despite being connected to the national power supply. Such firms, according to this Report, had altogether invested an average of $\$ 130,000$ each in their own private supply systems.

Similar investments were also made in private bore-holes due to unreliable water supply. The situation was the same in communication services where employment of messenger motor-cycles or radio transmitters was put in place because of weak telephone and postal systems. The Report concluded that Nigeria's weak infrastructural development had clearly reduced productivity of firms while accelerating inflation rates in the country.

The declining trend in the industrial electricity consumption by manufacturers is certainly the response of private industrialists to the poor quality of the public electricity supply. For example, industrial electricity consumption accounted for about 53\% of total consumption in 1965/66. This share persistently declined overtime with weaker performance of NEPA Plc to 40\% in 1970/80; 37.2\% in 1980/81 and 30\% in 1989 (News Watch Magazine, May 30, 1989: 14-19). Thus, the demand responses of many industrial and commercial electricity consumers to poor services have been to render NEPA Plc as a stand - by power supply source as they attempted to substitute a more expensive captive supply to minimise the economic cost of their production and consumption activities.

The market situation in the other utilities sub-sector of transportation, communication and water equally presented a dismal performance story as in the electricity. This was confirmed by government in the 1975-80 National Development Plan that public enterprises produced intolerable poor service 
(1975-80 Plan Document, Vol. 1: 229). This was clearly illustrated by an unimpressive probability of calls connecting, mails tampering or mails not reaching their destination except after considerable delay or not at all, which characterised the communications industry within that plan period and still obtained to a large extent in the 1980s particularly before the introduction of SAP.

For example, there were series of unfulfilled demands reaching about one - third of NITEL's installed capacity of about 300,000 lines up till 1986. Private substitution of transportation, radio and courier service for NITEL and NIPOST services were testimonies that things were not well with these public enterprises in terms of production to meet demand of consumers (Iwayemi,1990).

CEAR/NIDB Report of 1991 provided a comprehensive discussion on the poor state of the provision of water to most urban centres in Nigeria. These studies revealed the fact that bore-holes, wells and tanker supplies provide expensive alternatives for higher income consumers while lower income households resort to less healthy alternatives with ailment consequences.

In recognition of the commercial objectives of public enterprises, it would be economically desirable for public to embark on the simultaneous determination of investment finance and pricing decisions. Contrary to this desire, pricing and investment decisions were treated under statuary guidelines as two unrelated variables. Thus, under ministerial directives, tariffs (user-charges) were statuary fixed below production costs under the pretext of the subsidisation policy. Hence such tariffs did not reflect the scarcity values of utilities inputs. Table 1 shows operating costs, average costs, and average revenue of electricity during the periods between 1983 and 1987.

Table1. Electricity Total Operating Cost, Average Cost and Average Revenue between 1983 and 1987

\begin{tabular}{|c|c|c|c|c|}
\hline Year & $\begin{array}{c}\text { Total Operating } \\
\text { Cost (N Million) }\end{array}$ & $\begin{array}{c}\text { Average operating } \\
\text { Cost (Kobo/KWH) }\end{array}$ & $\begin{array}{c}\text { Average Operating } \\
\text { Revenue (Kobo) }\end{array}$ & $\begin{array}{c}\text { Operating Surplus/Losses } \\
\text { (N Million) }\end{array}$ \\
\hline 1983 & 370,307 & 6.8 & 7.0 & -37.27 \\
\hline 1984 & 365,102 & 5.9 & 7.4 & -11.92 \\
\hline 1985 & 410,142 & 5.6 & 7.4 & -58.63 \\
\hline 1986 & 544,835 & 7.3 & 7.0 & -26.73 \\
\hline 1987 & 651,053 & 8.7 & 7.1 & -81.04 \\
\hline
\end{tabular}

Source: NEPA Headquarter, Lagos.

Given the financial procedures, substantial financial losses characterised the operations of these public enterprises. Table1 illustrates the case of NEPA Plc for between 1983 and 1987 periods for which data exist. Apparently in all the years NEPA Plc incurred significant losses. Incidentally, the NRC, NAL, Water Board, NITEL and NIPOST were all visited with identical financial losses.

The quantifiable return on the large volume of investment in the public enterprise sector in Nigeria, for example, was not seen as satisfactory in the light of the realities of the country's economy in the 1980s. Almost all the enterprises operated at sub-optimal levels. There were huge losses in many cases, and these losses were charged against public treasury.

According to Obasanjo:

It is conservatively estimated that the nation may have lost about $\$ 800$ million due to unreliable power supply by National Electric Power Authority and another $\$ 440$ million through inadequate and inefficient fuel distribution. And the figures like this do not even tell the whole story. They cannot for example, capture the scope of human suffering and even loss of lives caused by shortage of petroleum products. That is not to mention the frustration and debilitation of the informal sector where business centres, repair workshops, hair dressing salons etcetera depend on steady supply of electricity to function (Anyebe, 2012:144).

In some of these organisations, cases of large-scale mega corruption were rampant. Permanent officials colluded with political executives to engage in corrupt practices. For example, in 2014 it was alleged by the Governor of the Central Bank of Nigeria (CBN Governor) that out of $\$ 67$ billion worth of crude oil shipped by the NNPC between January 2012 and July 2013 only $\$ 47$ billion was recorded by the CBN, leaving $\$ 20$ billion unaccounted for. He also revealed that within the same period, the NNPC failed to remit a whopping $\$ 49.8$ billion of oil proceeds to the Federation Account (Anyebe, 2018). 
After a series of verbal outbursts which generated a lot of controversies among industry operators including labours, organised private sector operators and financial experts the CBN governor appeared before the legislature and quoted another figure ( $\$ 12$ billion) - to the consternation of many Nigerians (leadership, Friday December 2014). For this singular act the CBN governor (who later became the Emir of Kano), was placed on indefinite suspension and a forensic audit was ordered. What the government and the NNPC later said was that it was only $\$ 10.8$ billion that was unaccounted for, which is still a huge sum of money. According to Imimole et al (2014) the Academic Staff Union of Universities' protracted strike of 2013 could have been averted if part of this amount was released to them. Merit-based recruitment and promotion were usually replaced by appointments and promotions based on patronage and clientelism and other forms of favouritism which in most cases involve corrupt practices.

Public enterprise's inability to live up to expectation in terms of their physical and financial performance has created a crisis of confidence which has been one of the reasons for the call for public enterprises' institutional reforms. In fact, the cumulative effects of this crisis, illustrated by the poor quality of services and financial losses earlier mentioned, have kept industrial growth and socioeconomic development much below what is attainable by the economy (Iwayemi, 1990 andAyodele, 1996). Therefore, the need to improve the performance of public enterprises underpins the privatisation and commercialisation policy embodied in the public sector reform programmes under SAP.

It should however, be noted that the discussion of the performance of Public Enterprises should not just focus on their profit and loss record but on their overall efficiency and accountability (Laleye, 2002). One major challenge is the difficulty of stating in measurable terms the results that Public Enterprises are expected to achieve. This difficulty is linked partly to the rather board objectives of the public enterprises (they are not easily amenable to clear and specific targets within a given time frame) and partly to the inadequacy of the resources put at their disposal. In addition to lack of clarity in the objectives, some of them conflict or raise conflicting expectations. Conditions that would facilitate the assessment of Public Enterprises would include the following: fixing precise and realistic targets to be achieved within specified time-frames, adopting efficiency maximisationas the indicator of rational use of resources; and building consensus are the objectives and targets so that conflict of expectations can be avoided. Actual measurement of performance can focus on return on assets and labour productivity.

The closest attempt at performance measurement in some SSA countries since the 1980s was the use of performance contracts. The performance contract or plan is an agreement between a government and the management of a public enterprise, stating the objectives to be achieved within a given time and conditions for achieving the objectives (Laleye, 2002).

Under normal conditions, the agreement includes a formal commitment of the government to provide the necessary resources for the enterprise. Nigeria is one country that has tried to use performance contracts but with rather poor results. The government did not fulfil its part of the bargain and showed no interest in monitoring the impact of the contracts. The experience in Nigeria contrasts with the successful use of performance contracts in France, South Korea, and a few Latin American countries.

Poor performance of Public Enterprises resulted in the introduction of some reform measures in Nigeria as early as in the 1970s. A good example is a 1979 two-year management services agreement with Rail India Technical Services and the Dutch Royal Airline to assist in improving the performance of the then Nigerian Railway Corporation and the Nigeria Airways, respectively. The agreements were signed in 1979, but the temporary improvement in services could not be sustained. Obviously, achieving improved performance in Public Enterprises requires more far-reaching reforms and greater commitment on the part of the leadership.

\section{CONCLUSION AND RECOMMENDATIONS}

The quantifiable return on the huge volume of investment in the public enterprise sector in Nigeria, for example, was not seen as satisfactory in the light of the realities of the country's economy in the 1980s. Most of the enterprises operated at sub-optimal levels. There were huge losses in many cases, and these losses were charged against public treasury. The phenomenon of external control is contrary to the principle of autonomy granted to the public enterprises. The enterprise's inability to live up to 
expectation in terms of their physical and financial performance has created a crisis of confidence which has been one of the reasons for the call for the privatisation of the sector in Nigeria.It was, therefore, recommended that achieving improved performance in public enterprise sector in the country requires more far-reaching reforms and greater commitment on the part of government.

\section{REFERENCES}

[1] Anyebe A.A. (2018). Public Enterprise: A Discipline at a Crossroads in Nigeria. Zaria: Faith Printers International, Nigeria.

[2] Anyebe A.A. (2012). Development Administration: A Perspective on the Challenge in Nigeria.(Zaria: Shereef Salam Press).

[3] ASCON (1983).Management Problems of Public Enterprises and Parastatals. The Report was submitted to the Federal Government of Nigeria in 1983

[4] Ayodele, A. I. (1996). Public Versus Private Sector Roles in Economic Management. A Paper Presented at NCEMA Senior Policy Seminar on Policy Issues on the Nigeria Economy July 30-August 2, 1996.

[5] Ayodele, A. I. and Sesan, I. (1995). The Privatisation and Commercialisation Policy in Nigeria: Some Theoretical and Empirical Issues". In Uniamikogbo (ed). Issues in Privatisation and Commercialisation of Public Enterprises in Nigeria.Department of Economics, Edo State University, Ekpoma, Nigeria.

[6] CEAR/NIDB Report (1991)

[7] Fabura, B. A. (1984). Strategy Formulation and Political Intervention in State-owned Companies.In LDCs RVB Newsletter and Research Paper 4 (1).

[8] Federal Government of Nigeria: The 1975 - 80 Plan Document.

[9] Imomole, B. and Izuagie, L. (2014). Corruption in Nigeria: Implications for National Development. In I. Walter and L.R. Momoh (eds.). Governance, Peace and Security in Africa. Benin-City: Ambik Press.

[10] Iwayemi, A. (1990). Oil and Nigeria: The Good, the Bad and the Ugly, $5^{\text {th }}$ Distinguished Faculty of Social Science Annual Lecture, University of Ibadan, September 26.

[11] Laleye, M. (2002).Public Enterprises. In L. Adamolekun (ed.), Public Administration in Africa: Main Issues and Selected Country Studies (Ibadan, Spectrum Books).

[12] Leadership (2014).Headline - Makers of 2014. Friday December 26, 2014. Available at www.leadership.ng

[13] NewsWatch Magazine, (1989). May 30, 1989

[14] Ojobo, J. A. (2010). Public Enterprises Management.Gwagwalada, Abuja: Chartered Graphic Press.

[15] World Bank (1990).Report of Public Enterprises (New York: Oxford University Press).

Citation: Prof. Adam A. Anyebe. "An Assessment of the Performance of Public Enterprise Sector in Nigeria". International Journal of Political Science (IJPS), vol4, no.2, 2018, pp.41-46. doi:http://dx.doi.org/10.20431/2454-9452.0402004.

Copyright: (1) 2018 Authors. This is an open-access article distributed under the terms of the Creative Commons Attribution License, which permits unrestricted use, distribution, and reproduction in any medium, provided the original author and source are credited. 